\title{
Cultural Dynamics \\ in a Globalized World
}

Editors

Melani Budianta

Manneke Budiman

Abidin Kusno

Mikihiro Moriyama

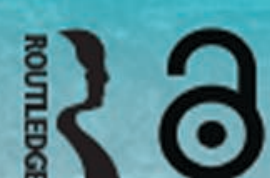


PROCEEDINGS OF THE ASIA-PACIFIC RESEARCH IN SOCIAL SCIENCES AND HUMANITIES, DEPOK, INDONESIA, NOVEMBER 7-9, 2016, TOPICS IN ARTS AND HUMANITIES

\section{Cultural Dynamics in a Globalized World}

Editors

Melani Budianta

English Studies Program, Literature Department, Faculty of Humanities,

Universitas Indonesia, Depok, Indonesia

Manneke Budiman

Faculty of Humanities, Universitas Indonesia, Depok, Indonesia

Abidin Kusno

Faculty of Environmental Studies, York University, Toronto, Canada

Mikihiro Moriyama

Department of Asian Studies, Faculty of Foreign Studies, Nanzan University, Nagoya, Japan 
Routledge is an imprint of the Taylor \& Francis Group, an informa business

(C) 2018 Taylor \& Francis Group, London, UK

Typeset by V Publishing Solutions Pvt Ltd., Chennai, India

Although all care is taken to ensure integrity and the quality of this publication and the information herein, no responsibility is assumed by the publishers nor the author for any damage to the property or persons as a result of operation or use of this publication and/or the information contained herein.

The Open Access version of this book, available at www.tandfebooks.com, has been made available under a Creative Commons Attribution-Non Commercial-No Derivatives 4.0 license.

Published by: CRC Press/Balkema

Schipholweg 107C, 2316 XC Leiden, The Netherlands

e-mail: Pub.NL@taylorandfrancis.com

www.crepress.com - www.taylorandfrancis.com

ISBN: 978-1-315-22534-0 (eBook) 


\section{Table of contents}

Organizing committee

Social norms, social movements, and ethics

Foreword by Manneke Budiman 3

$\begin{array}{ll}\text { Social conflict resolution and the need for a system of ethics } & 7\end{array}$

A. Seran

Editorial cartoons and the visualization of corruption at the beginning of the New Order (1968-1974): Case study of Indonesia Raya daily

A.M. Padiatra \& A. Setiawan

The 19th-century Undang-Undang Ternate: Structure and power analysis

P.F. Limbong \& T. Pudjiastuti

KPK and the commitment of the Indonesian government to eradicate

corruption (2004-2014)

H.R. Mufti \& B. Kanumayoso

Autonomy and historicity of an individual as a moral agent

J.P. Kamuri \& H.S. Pratama

Redefining ethics and morals in colonial space: Creation of leisure in the colonies

in Van Zeggelen (1911)

C.T. Suprihatin

Moral consciousness in Kresna Duta's characters: An analysis through moral theory of Lawrence Kohlberg and the discourse ethics of Jürgen Habermas

M.W. Nurrochsyam \& E.K. Ekosiwi

Transposition of epistemology to hermeneutics: Richard Rorty's philosophy

of edification

F. Hadinata \& A. Y. Lubis

Leader's attitude towards terrorism: A critical discourse analysis

of Dr. Mahathir Mohamad's diplomatic letters

B.E. Pranoto \& U. Yuwono

Stimulus of request in Japanese and its relation to wakimae as a cultural context:

A discourse analysis on culture in conversation

Filia, N.J. Malik \& U. Yuwono

Toraja people's involvement in Qahhar Mudzakkar's DI/TII movement

R.D. Kabubu \& Abdurakhman

Digital art and its uniqueness without aura 
Accelerating Quentin Meillassoux with Antonio Negri: On the deadlock of speculative realist ontology

H. Y. Polimpung \& A. Y. Lubis

Historical aspects of Babad Sepehi

105

Y. Irawan \& K. H. Saputra

Disturbance of local democratization: Riot in Tuban election 2006

M. Sodikin \& Abdurakhman

The concept of homo ecologicus spiritual-ethical (an ethical reflection on the ecological humanism concept of Henryk Skolimowski)

F. Fios \& G. Arivia

Applications of spiritual-ethical homo ecologicus in the local indigenous context of Indonesia (a case study in the Oenbit village, East Nusa Tenggara province)

F. Fios \& G. Arivia

Music's critical function to social conditions

K. Andjani \& A. Y. Lubis

No-self: Reflections on ethics and identity

J. Jiwanda \& A. Y. Lubis

Perhimpoenan Kaoem Betawi: The struggle for identity and role in the Indonesian

National Movement (1923-1941)

Siswantari

Freedom of expression at the Jakarta Art Centre during Soeharto's New Order

S.N. Kusumastuti

The eco-spiritual ethics of Balinese Hindus challenged: The case of the reclamation of Benoa Bay

I.N. Suwidjana, G. Arivia, G. Dwikartika \& R. Lustanto

Vergangenheitbewältigung/coming to terms with the past: Demystifying Hitler and the Nazi regime in German comics

L. Kurnia

The legacy of Soeharto's New Order: Power sustainability through control

of information media

F. Gani

Public reason and the rise of populism in post-reformation Indonesia

G.C. Acikgenc \& H.S. Pratama

Construction of grief in obituary texts in German (2012-2015)

S.P. Suganda

The political as the ontological primacy: On Ernesto Laclau's thoughts

D. Hutagalung \& A. Y. Lubis

Roles and contributions of participants in broadcast talk

M.K. Wardhani \& B. Kushartanti

Representing nation/homeland, gender, and religion

Foreword by Melani Budianta

Beyond the collections: Identity construction at the National Museum of Indonesia 
Formation of Javanese Malay identities in Malay Peninsula between the 19 th and 20th centuries

The representation of national identity in the film Tanah Surga Katanya

L.S. Limanta \& L. Kurnia

Building national identity in the border areas: The critical success factors analysis in the management of community radio in Sintang, West Kalimantan

L.H. Kurnia

Heimat for three generations of immigrants in Germany: An analysis

of Turkish-German films

M.R. Widhiasti \& M. Budianta

Representation of India as the root of identity in the film adaptation of

The Namesake

R. A. Setyaningrum \& D. Hapsarani

Contested representation of Dutch Americans in Washington Irving's

A History of New York

M. Baga \& M. Budianta

Indonesian novels' phenomenon of mingling and competing with cultural exposure

I. G.A.A.M. Triadnyani

Funding politics in European film festivals and its impacts on the development of Indonesian cinema

R. Ihwanny \& M. Budiman

The Lunar New Year and Guanggunjie 光 棍 节 tradition: The representation of China in the Lentera broadcast by China Radio International

R.P.S. Hadi \& M. Budiman

Mandarin education and contemporary Chinese-Indonesian identity repositioning:

Between recinicization and cosmopolitanism

Q. Q. Luli \& M. Budiman

Appropriating South Korean popular culture: I-pop and K-drama remakes in Indonesia

S.M.G. Tambunan

Positive body image activism in collective (@effyourbeautystandards) and personal (@yourstruelymelly) Instagram accounts: Challenging American idealized beauty construction

D. M. Wuri \& S.M.G. Tambunan

Problematizing sexualized female images and Donald Trumps' immigration stance in video games: An analysis of Let's Play videos on YouTube

S. Angjaya \& S. M. G. Tambunan

Constructing an imagined community of fandom and articulating gender identity:

A case study on Indonesian female football fans' participation in social media

N. Azizi \& S.M.G. Tambunan

Martha Nussbaum's central capabilities read violence against women in Indonesia

H.P. Sari

Afghan women's repression by patriarchy in My Forbidden Face by Latifa 
Memory of the female protagonist in relation to gender oppression in Catherine Lim's

The Teardrop Story Woman

J.D. Sukham \& D. Hapsarani

Women and corruption in Okky Madasari's 86 and Anggie D. Widowati's Laras:

A feminist study

A. Akun \& M. Budiman

Contesting representations in the gendered space of politics: Hillary Clinton's

representations in Living History, A Woman in Charge, and Her Way

D. Hapsarani \& M. Budianta

Construction of woman in the Sundanese magazine Manglè (1958-2013):

A corpus-based study of metalinguistic signs

S. Yuliawati \& R.S. Hidayat

Metaphors of women in the Sundanese magazine Manglè (1958-2013):

A corpus-based approach

A. Alkautsar \& T. Suhardijanto

The collocation and grammatical behaviour of two nouns denoting women in

Sundanese: A corpus-based analysis of language and gender relationship

P.G. Bagasworo \& T. Suhardijanto

The role of women in Javanese literature: A case study of Serat Gandakusuma

SJ 194 NR 324 and SW 5 SB 47

381

W.P. Sudarmadji \& A. Prasetiyo

Posuo, space and women: Buton community's customary tradition and its preservation

I. Ibrahim \& M. Budiman

Cosmopolitan female Muslim travellers in Berjalan di Atas Cahaya

S. Hodijah \& C.T. Suprihatin

The mosque as a space for Minangkabau women

H.F. Agus \& M. Budianta

The realisation of metaphorical speech act in a religious themed text: Pragmatics analysis on a popular religious self-help book

S. Altiria \& A. Muta'ali

Imagery characters and ideology of Islamic fundamentalism: Adaptation of the novel Les Étoiles de Sidi Moumen and the film Les Chevaux de Dieu

D. Jinanto \& J. Tjahjani

School-centric Islamic education in Indonesia: A deconstructive analysis

of Muhammad Abed Al-Jabiri

N.S. Wibowo \& Naupal

Developing English teaching materials based on Content-Based Instruction (CBI)

approach for the Islamic management and banking students at IAIN Imam Bonjol Padang

Elismawati \& Mukhaiyar

The main ideas of Muhammad Mursi's speech at the 67th United Nations

General Assembly: A critical discourse analysis

D. Lu'lu \& A.T. Wastono

An ontology of violence based on moral teachings: A case study of Salafi Wahabi radicalism and the story of Kresna Duta (Ambassador Kresna) 
The story of caliph Abu Bakr, Umar, Usman, and Ali to the battle of Hasan and Husain in Karbala: Islamic epics from Ambon

D. Kramadibrata

Islamic discourse in German online mass media: Intra-migrant Muslim perspective on refugee issues. Shift in the position of three Muslim individuals: Feridun Zaimoglu, Necla Kelek, and Navid Kermani

L. Liyanti

Abuya Dimyathi: A charismatic mursyid of tarekat Syadziliyah during

the New Order regime (1977-1982)

J. Syarif \& Y. Machmudi

\section{Regional identity and cultural heritage}

$\begin{array}{ll}\text { Foreword by Mikihiro Moriyama } & 481\end{array}$

Wawacan Samun: Between the convention and the creation of Wawacan 485

M. Holil \& T. Pudjiastuti

Piwulang teachings in Serat Darmasaloka

S. Rohman \& D. Kramadibrata

Old Papuan manuscripts: A general review

T. Pudjiastuti

Articulation and contestation of cultural identities in Riau Province:

The case of 'Mandau Regency'

S. Basuki \& M. Budiman

Utilization of the Senjang tradition as cultural identity of the people

in Musi Banyuasin, South Sumatra

A. Ardiansyah \& T. Christomy

Colophon in the Hikayat Pandawa manuscript

M. Buduroh \& T. Pudjiastuti

Bismaprawa: An Old Javanese text from the Merapi-Merbabu tradition derived

from Adiparwa

A. Kriswanto \& D. Puspitorini

Uttaraśabda in Java and Bali

A. Kurniawan \& D. Puspitorini

Loloda in the world of Mollucas: The decline of the political entity in Loloda from

Kolano to Sangaji

A. Rahman

Votive tablets in Buddhist religious rituals in the Nusantara archipelago

from the 7th-10th centuries AD

A. Indradjaja \& W.R. Wahyudi

Tracing religious life in the ancient Bali period: An epigraphical study

N.K.P.A. Laksmi \& W.R. Wahyudi

Ancient water system and reservoir at the Muarajambi archaeological site

C.M. Arkhi \& W.R. Wahyudi

Association of Borobudur Temple with the surrounding Buddhist temples

N.A. Izza \& A. A. Munandar 
Variety of distinct style scripts in inscriptions found in Mandalas of the late

Majapahit era: An overview of the paleography to mark religious dynamics

N. Susanti

Religious communities in the late Majapahit period at Pasrujambe site, Lumajang

A. Rahayu \& N. Susanti

Particles pwa and $t a$ in the Old Javanese language

\section{Puspitorini}

The role of Mandalas in the old Javanese religious community

in Tantu Panggélaran

T.I. Setyani \& T. Pudjiastuti

Signatures in Hikayat Sultan Taburat's manuscripts: The existence of scribes in the 19 th century

R. A. Suharjo \& T. Pudjiastuti

Management of cultural heritage sites: A case study of Perkampungan Adat

Nagari Sijunjung

F. Amril

Nusantara philosophy: The study of meanings based on Indonesia's local wisdom in East Java and East Nusa Tenggara

L. Tjahjandari, T.I. Setyani \& L.H. Kurnia

Silpin's artistic freedom in the creation of Tathagata statues on the Rupadhatu level at Borobudur

G. Mentari \& A.A. Munandar

Spatial narrative in a traditional Sundanese village

T. Christomy

Symbolic meaning of the Srāddha ritual in the Merapi-Merbabu

Putru Kalěpasan text

I. M. Suparta \& T. Pudjiastuti

Ancient religious artworks in Central Java (8th-10th century AD)

661

A.A. Munandar

Global economy, urbanization and social change

Foreword by Abidin Kusno

A toponymy based study on waterway trade in the ancient Mataram era

(9th-11th century AD)

G. A. Khakam \& N.S. Tedjowasono

Development of Mandar's maritime trade in the early twentieth century

681

\section{A. R. Hamid}

The golden age of the East Indonesian economy during the NIT era (1946-1950)

\section{Evita \& Abdurakhman}

Food culture and land use in ancient times

695

Taqyuddin \& N. Susanti 
The Treaty of 1855: Early American shipping, commerce, and diplomacy in the Indonesian archipelago (1784-1855)

Y.B. Tangkilisan

Individual unit of analysis in the debate on the methodology of economics

as a social science

H.S. Pratama

Colonialism and segregation: An analysis of colonial policies in the Strait

of Malacca 1795-1825

T.R. Fadeli

The impact of economic modernization on the lifestyle of the Palembang society in 1900-1930

N.J. Utama \& L. Sunarti

The impact of modernization on the economy for fishermen in Makassar City

P. Rifal \& L. Sunarti

Colonial modernity, Indonesian nationalism, and urban governance:

The making of a colonial city, Surabaya (ca. 1890-1942)

A. Achdian

Efforts to overcome the problems of food demand in South Sulawesi

in the Guided Democracy period (1959-1965)

A.A.A. Mulya \& M. Iskandar

A study on how Uber seizes the transportation space in Jakarta

D. T. Gunarwati \& L. Kurnia

Commuter line e-ticketing system and the disciplining of urban citizens

A. Sandipungkas \& L. Kurnia

The dynamics of production and consumption in Islamic housing

775

J.D. Shanty \& M. Budianta

Typical French linguistic process on Facebook

F.G. Junus \& M. Laksman-Huntley

Indonesian-English code-switching on social media

M. Aulia \& M. Laksman-Huntley

Use of English hedges by 12 learners in academic writing: A case study of pragmatics

Y. Widiawati \& F.X. Rahyono

"You are what you eat ... and post": An analysis of culinary innovation and cultural branding in Panggang Ucok's Instagram account

S.M.G. Tambunan \& M.R. Widhiasti

The use of cohesive devices in deaf and hearing children's writing

Novietri \& B. Kushartanti

Acoustical analysis of pitch contour in autism spectrum disorder

L. Roosman, T.W.R. Ningsih, F.X. Rahyono, M. Aziza \& Ayesa

Characteristics of word duration in children with autism spectrum disorder

T.W.R. Ningsih, F.X. Rahyono \& Ayesa

Experimental approach of perception toward autism spectrum disorder intonation

F.X. Rahyono, T.W.R. Ningsih, Ayesa \& M. Aziza 
Changes in the virtual reference services at Bina Nusantara University to meet users' information needs

M. Septiana \& T.A. Susetyo-Salim

Students' information behavior and the use of library reference service at Surya International School, Jakarta

R. R. Romadon \& T.A. Susetyo-Salim

Transformation from conventional to virtual library reference services at Surya International School, Jakarta

D.P. Prabowo \& T.A. Susetyo-Salim

Empowering students with information literacy education as one of the library reference service functions at Surya International School, Jakarta

E. Cahyani \& T.A. Susetyo-Salim

Reconstructing Joko Widodo's national education ideology: A critical discourse analysis on the policies in Indonesia

R. M.P. Silalahi, N.J. Malik \& E. Mulyajati

Nationalism and neoliberalism in education: A critical discourse analysis

of presidential speeches in Indonesia's reform era

R. M.P. Silalahi, N.J. Malik \& U. Yuwono

Values of neoliberalism in education: A comparative study of Indonesian presidential speeches in the New Order and Reform Era

R. M.P. Silalahi, U. Yuwono \& Y.J. Aminda

Meeting the challenges of global competition: Preserving and revitalizing the cultural heritage of Bagansiapiapi

A.A. Harapan \& L. Mariani

Preserving and maintaining traditional culture through interior design: A case study of Torajan elements in a local restaurant P. Salim

The toponymy of the ancient port city of Gresik in the northern coastal area of Java 921

Z. Muhatta \& N. Soesanti

Author index 


\section{Organizing committee}

\section{STEERING COMMITTEE}

Rosari Saleh (Vice Rector of Research and Innovation, Universitas Indonesia)

Topo Santoso (Dean Faculty of Law, Universitas Indonesia)

Ari Kuncoro (Dean Faculty of Economics and Business, Universitas Indonesia)

Adrianus L.G. Waworuntu (Dean Faculty of Humanities, Universitas Indonesia)

Arie Setiabudi Soesilo (Dean Faculty of Social and Political Sciences, Universitas Indonesia)

\section{INTERNATIONAL ADVISORY BOARD}

Peter Newcombe (University of Queensland, Australia)

Fred Piercy (Virginia Tech University, Australia)

Frieda Mangunsong Siahaan (Universitas Indonesia, Indonesia)

James Bartle (University of New South Wales, Australia)

Elvia Sunityo Shauki (University of South Australia, Australia)

\section{SCIENTIFIC COMMITTEE}

Manneke Budiman

Isbandi Rukminto Adi

Beta Yulianita Gitaharie

Surastini Fitriasih

Sri Hartati R Suradijono

Elizabeth Kristi Poerwandari

CONFERENCE DIRECTOR

Tjut Rifameutia Umar Ali

CONFERENCE VICE-DIRECTOR

Turro Wongkaren

\section{ORGANIZING COMMITTEE}

Dewi Maulina (Faculty of Psychology, Universitas Indonesia)

Intan Wardhani (Faculty of Psychology, Universitas Indonesia)

Elok D. Malay (Faculty of Psychology, Universitas Indonesia)

Josephine Rosa Marieta (Faculty of Psychology, Universitas Indonesia)

Teraya Paramehta (Faculty of Humanities, Universitas Indonesia) 
Nila Ayu Utami (Faculty of Humanities, Universitas Indonesia)

Priskila Pratita Penasthika (Faculty of Law, Universitas Indonesia)

Efriyani Djuwita (Faculty of Psychology, Universitas Indonesia)

Destri Widaya (Faculty of Economics and Business, Universitas Indonesia)

\section{WORKSHOP COMMITTEE}

Corina D.S. Riantoputra (Faculty of Psychology, Universitas Indonesia)

Fithra Faisal Hastiadi (Faculty of Economics and Business, Universitas Indonesia)

Mirra Noormilla (Faculty of Psychology, Universitas Indonesia)

\section{TREASURERS}

Robby Oka Yuwansa (Faculty of Psychology, Universitas Indonesia)

Nurul Husnah (Faculty of Economics and Business, Universitas Indonesia) 


\title{
The representation of national identity in the film Tanah Surga Katanya
}

\author{
L.S. Limanta \& L. Kurnia \\ Department of Literature, Faculty of Humanities, Universitas Indonesia, Depok, Indonesia
}

\begin{abstract}
Identity is central in steering people's life. However, it is not something that is fixed and solid. As Hall states, identity is more of a process than a product or a fixed entity. National identity is a more sophisticated construction that involves a positioning. It becomes more complicated if it concerns those who live in the border areas. Drawing on the concepts from Anderson, Hall, Kolakowski, Smith, and Edensor on identity, national identity, and representation, this paper analyses how national identity is represented in the film Tanah Surga Katanya... (Heaven on Earth, They Say...). From the analysis it can be concluded that the representation of national identity in the film Tanah Surga Katanya..., which is carried out through the usage of symbols (flag and currency), memory, and rituals, has been successful in showing that people who live on the border areas may have multiple and competing national identities, and that national identity is a construction that cannot be solidified into a single meaning.
\end{abstract}

\section{INTRODUCTION}

Everybody needs an identity. It gives a sense of security for someone to play out his/her role in society. A lack of identity can lead to confusion. However, identity is not something that is fixed and easy to determine. As Hall (1990) argues, identity is a production, not a product, and it is "never complete, always in process, and is always constituted within, not outside, representation" (as cited in Rutherford, p. 222). The key point of this identity construction within representation is positioning. Hence, according to Hall, there is always "a politic of identity, a politic of position" (p. 226). Identity is very important since, as Castells (2010) defines it, it is "the people's source of meaning and experience" (p. 6). By this definition, identity gives a sense of direction to people's behaviour and an orientation of their values. Furthermore, in line with Hall's idea, Castells sees identity as "the process of construction of meaning" (ibid.).

Thus, identity is always constructed in a certain social context. This paper analyses how national identity is represented by the characters in the film Tanah Surga Katanya... (2012), their struggles, experience, and the positioning of themselves as Indonesians.

\subsection{The context of the film}

This film was produced in 2012 and won five awards in the 2012 Indonesian Film Festival, namely the Best Film, the Best Director, the Best Original Screenplay, the Best Supporting Actor, and the Best Art Direction (Siregar, 2012). It tells a story of an ex-volunteerfighter of the 1965 Indonesia-Malaysia confrontation, Hasyim, who lives in the border area between West Kalimantan (Indonesia) and Serawak (Malaysia) with his two grandchildren, Salman and Salina. Meanwhile, Haris, Hasyim's son, prefers to live in Serawak as it promises a brighter future. Haris is already married to a Malaysian woman and is quite established economically. One day, Haris comes home to take his father and two children to go to 
Serawak with him. However, Hasyim fervently declines Haris' invitation in a spirit of heroism, as he fought against Malaysia in the 1965 confrontation, and nationalism.

From a superficial view, the conflict between Hasyim and Haris can be interpreted as nostalgic and nationalistic attitudes against pragmatic and realistic ones. However, this film presents a more profound, subtle, and complicated positioning of each side. The setting in the film is the border area between West Kalimantan (Indonesia) and Serawak (Malaysia). Historically speaking, Indonesia and Malaysia have had a long history of tensions beginning with the Confrontation from 1961 to 1966 (Omar, 2010). Although the relationship was restored under the late President Suharto, the conflict between the two countries continued over territorial disputes, particularly Ligitan and Sipadan Islands, and the Ambalat sea block. While this short historical survey does not emphasize the practical political tensions between the two countries over territorial disputes, it provides a background to understand Hasyim's attitude and self-positioning towards Malaysia.

Another aspect relevant to the discussion of the construction of national identity and its representation is the borderland itself. As the characters move in and out of the border between Indonesia and Malaysia, the borderland plays an important role in how they position themselves. The border area is actually not natural and difficult to determine. As Diener and Hagen (2010) state, "Professional geographers soon conclude that all borders are arbitrary, subjective, and the result of human decisions, not forces of nature" (p. 8). Furthermore, Diener and Hagen emphasize the cultural perspective of border and conclude that recent studies view border areas "as sites of cultural interaction, exchange, and possibly hybridity" (p. 10). In this connection, Puryanti and Husain's study (2011) on the negotiation between people and the state in the borderland of Indonesia-Malaysia in Sebatik Island is important for the discussion:
"The relationship with Malaysia, for example, cannot only be viewed in terms of 'us' and 'them', as is suggested when people talk about national identity. ... It would be illusive to measure their nationalism only from their use of the Ringgitin their daily life. ... A focus on borders can show how citizens relate to their nation-state in which loyalties are competing and multiple identities are managed on a daily basis, especially when there are economic disparities between two neighbouring countries like Indonesia and Malaysia in their border areas." (p. 117)

From this quotation, it is clear that someone's identity cannot be determined easily on the surface from what one does. However, as in the case of Haris in the film, he can position himself in such a way as to form multiple identities or to contain the contestation of identities within him.

\subsection{Nation and national identity}

Before analysing the representation of national identity in the film Tanah Surga Katanya ...., it is necessary to clarify the idea of nation and national identity. Anderson (2006) defines a nation as "an imagined political community" (p. 6). Furthermore, he explains that it is imagined because each member of the community has the idea that s/he belongs to a community in which most of its members very likely never meet each other. Thus, her/his membership to the community practically exists in her/his mind. The effect of this idea is that people might sometimes adhere to the idealization of the imagined community (its values, norms, rules), but at some other time they might contest it and prefer to live her/his concrete and practical daily life without necessarily complying with the idealization. This will be elucidated further in the analysis of the film, particularly in the case of Haris.

The next clarification needed is the idea of national identity which is more difficult to define. Some theorists have tried to identify the elements that construct national identity. For Stuart Hall, national identity is "an example and, at the same time, a form of national cultural identity" (as cited in Wodak, Celia, Reisigl, \& Liebhart, 2009, p. 23). Furthermore, Hall defines national culture as 
"a discourse - a way of constructing meanings which influence and organize both our actions and our conceptions of ourselves ... National cultures construct identities by producing meanings about 'the nation' with which we can identify; these are contained in the stories which we are told about it, memories which connect its present with its past, and imaginings which are constructed of it." (ibid.)

Thus, it can be said that national identity enables people to identify themselves with the cultures of a nation through common stories, memories, and imaginings. However, the identification process might be experienced differently by members of the community since national culture is a discourse that "represents differences between social classes, between ethnic groups, or between the sexes" (ibid.).

Moreover, Kolakowski identifies five elements that characterize national identity, namely the national spirit or 'Volksgeist,' as expressed in the collective manners of behaviour, historical or collective memory, anticipation and future orientation, and the national body concerning the national territories, landscapes, and nature, and a nameable beginning, referring to the story of the 'founding fathers' or the beginning of time (ibid., p. 26). The relevant elements for the discussion in this paper are the first, second, and the third elements of Volksgeist, especially in Salman's attempt to project the image of Indonesia based on his life experiences and in the conflict experienced by Hasyim and Haris. Furthermore, Anthony D. Smith (1991) explains that members of a community or nation identify themselves as a part of it since they are united in a bond through "the use of symbols - flags, coinage, anthems, uniforms, monuments and ceremonies", and thus they are "reminded of their common heritage and cultural kinship and feel strengthened and exalted by their sense of common identity and belonging" (p. 16-17).

While it is true that national identity can be clearly represented in the use of symbols and in ceremonies, according to Edensor (2002), it is also "grounded in the everyday, in the mundane, details of social interaction, habits, routines, and practical knowledge" (p. 17). What happens in daily social life does not always go smoothly in parallel with the ideals of national culture. As Edensor further states, what is called "national" can even be "constituted and reproduced, contested and reaffirmed in everyday life" (p. 20). The analysis of the characters in the film especially Haris elucidates this point clearly.

\subsection{The representation of national identity in Tanah Surga Katanya...}

The film Tanah Surga Katanya... (Heaven on Earth, They Say...) represents the national identity in the quotidian life experiences of Indonesians who live in the borderland between Indonesia and Malaysia. The representation is done through the symbols (usage of national flag and currency), ceremonies (singing national songs, welcoming of the state officials), and the characters' actions (the position and choices they take), and memory (shared memories). The analysis in this paper shows that the representation contains contestation of meanings produced by the film characters.

First of all, the national identity is represented through the use of the Indonesian national flag or the Red-and-White flag. The flag is a common signifier for the Indonesian national identity, but in this film the use of the flag is applied to represent contested meanings. On the one hand, the Red-and-White flag represents a spirit of pride and heroism. This is shown through the characters Hasyim and Salman. The emotional attachment to the national flag is clearly shown first by Hasyim, and he passes it down to Salman later on. Hasyim is the only person in the village who still owns and keeps the national flag. For Hasyim, a former fighter in the conflict between Indonesia and Malaysia, the flag signifies the dignity and greatness of Indonesia. Therefore, he keeps the flag in a special box as a symbol of such dignity and greatness, almost like a sacred object (Figure 1). When the local officials come to the village and for the first time the Red-and-White flag is hoisted again after the Dwikora operation, i.e. the confrontation era, Hasyim attends the ceremony and stands in reverence while looking up at the flag from a distance (Figure 2). 


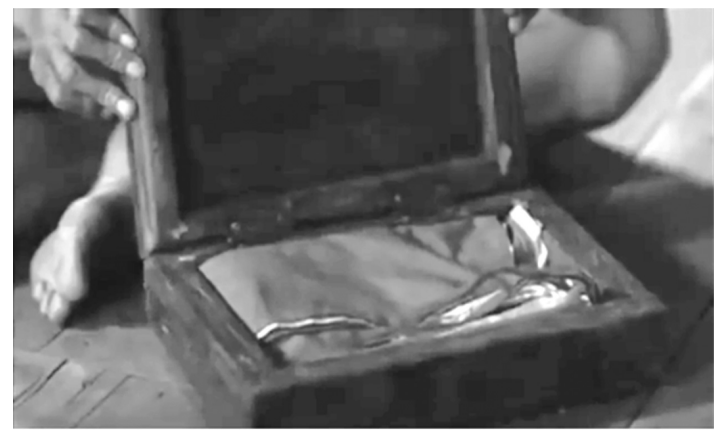

Figure 1. The Red-and-White flag.

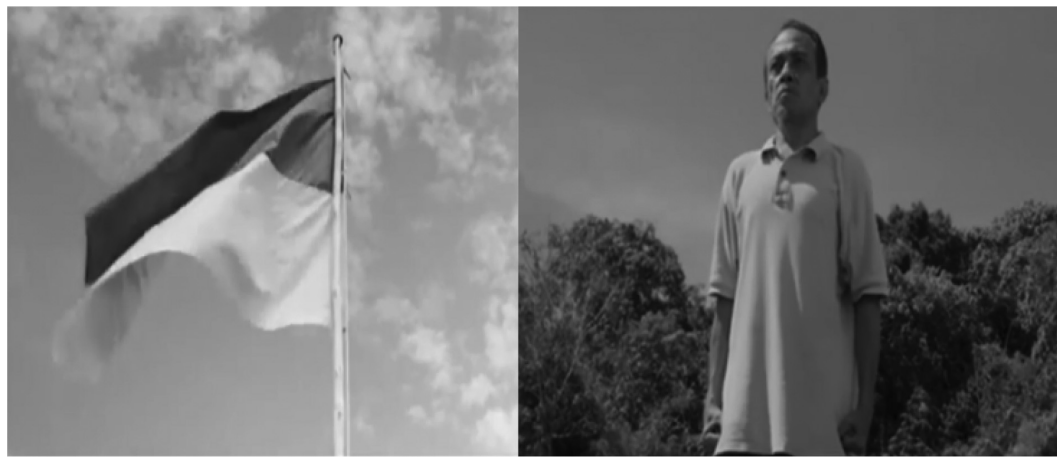

Figure 2. Showing reverence to the red-white flag.

Hasyim's attitude towards the flag and his memory of fighting against Malaysia is passed down to his grandson Salman who reveres it almost as sacred too. Thus, Salman strongly protests to an Indonesian salesperson (the second owner of the Red-and-White flag in the film) when he goes to the market in the Malaysian territory and sees the salesperson using the Red-and-White flag casually as a mat for his goods (Figure 3). Later on, when Salman has succeeded to collect some money and buys two pieces of sarong (intended formerly for his grandfather, Hasyim) and sees the same salesperson, he offers one piece of sarong to the salesperson in exchange for the Red-and-White flag. Salman's attitude clearly shows how he reveres the Red-and-White flag as a representation of dignity and greatness of the Indonesian national identity.

Ironically, the state elementary school, the representation of official educational institution in the village, and the village head, the extension of the government, do not own a national flag. The state's failure to provide even a single flag in the village, which is a symbol of national sovereignty and dignity, and the salesperson's ignorance and indifference towards the flag represent a contrasting meaning attached to the flag. In this case, the same object that symbolizes a national identity is presented as an unimportant or irrelevant object in people's daily life. The teacher, students, and people in the village are not aware of the need or the existence of the Red-and-White flag until the local government officials visit the school. Hence, although the Red-and-White flag is used in the film as the representation of a national identity imbued with pride and heroism, it is presented as an insignificant object without the weight of those meanings.

The next representation of the national identity in this film is done through the usage of currency. The Malaysian ringgit is depicted to be used within the Indonesian side of the borderland, and Dr. Anwar, the volunteer doctor in the village, finds this outrageous. 


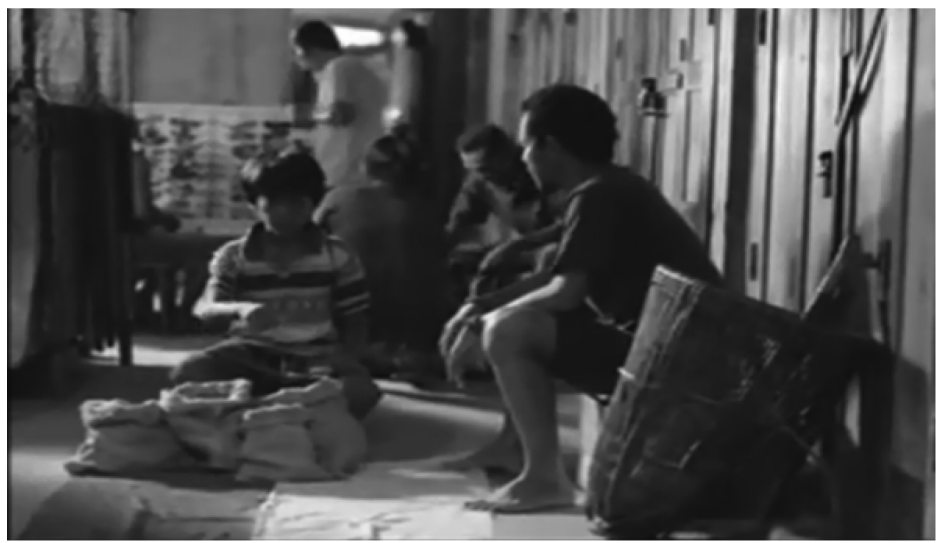

Figure 3. Contrasting meaning construction of the national flag.

He attaches the Indonesian national identity to the usage of currency and considers the use of the Malaysian ringgit in Indonesian land by Indonesians intolerable and dangerous because it can threaten the Indonesians' national identity. In this case, Dr. Anwar represents the superficial and ideal identification between the use of the Indonesian rupiah and national identity. While for Lized, an Indonesian boy who helps him bring his luggage and is tipped with rupiah, and for other people who live on the Indonesian borderland, the ringgit is the common currency they use for daily trading practices because they rely on doing business with their Malaysian neighbours.

As cited by Puryanti and Husain previously, it is "illusive to measure their nationalism only from their use the ringgit in daily life". This film thus represents competing ideas of what it means to be Indonesians. On the one hand, the usage of rupiah may signify the pride of being a part of Indonesia, but on the other hand, for the people who live in the borderland and rely on doing business with their Malaysian neighbours, the use of the ringgit is the only available meaningful economic practice since they depend on their neighbour's more bustling area. Meanwhile, competing and multiple identities are formed among the students who have never seen the rupiah and just learn that they are Indonesians from their teacher, Astuti, but still rely on their Malaysian neighbours. They may realize that they are Indonesians, but they use the ringgit to be part of Malaysia on a daily practical basis. In this case, the film shows that there are contested meanings of being a part of Indonesia through the national identity represented in the use of currency.

A further contestation of meaning in terms of national identity is represented through the ceremony of the singing of the national song. The Indonesian anthem, Indonesia Raya, is usually sung in official occasions like during a flag ceremony or welcoming government officials. In this film, the students in the elementary school only know one song, which is Kolam Susu (Pool of Milk), which tells the wealth and prosperity of Indonesia that is so abundant that anyone could 'turn sticks and rocks into plants'. While the song captures what is believed to be an image of the reality of the wealth of Indonesia's nature which has become a collective memory, the prosperity, in reality, is not enjoyed evenly by most of the Indonesians, especially those who live in the border area as presented in this film. Thus, this song is mainly used as an irony to criticize the government for not paying enough attention to the borderland.

The image of reality presented in this film is that the village suffers from severe inadequate facilities. The students only know the song Kolam Susu instead of the national anthem because they have forgotten it since the last teacher who taught the song has been replaced for a year, and the substitute teacher to teach the anthem has not been provided. The awareness of the importance of singing the national anthem emerges when the government officials visit the village. When welcoming officials, a flag ceremony is usually held, and the local 
students also perform in a talent show. In this occasion, Salman reads a poem which presents a counter-meaning to the construction of the belief and ideology built in the song Kolam Susu. In his poem, Salman tries to provide an image of reality he and his grandfather have experienced in their daily life. Table 1 shows the comparison between the song and Salman's poem to clarify this point.

Salman illustrates the big gap between the image of his grandfather's nationalism and sacrifice in defending his country and the image of reality that he and his grandfather experience. Hasyim has a serious heart problem, and it is very difficult to get proper health treatment for him due to many constraints, namely lack of financial capability, the long distance to the nearest hospital, and inadequate transportation. For Salman, the imagining of Indonesia in the song Kolam Susu is not translated in his daily life. Salman has to work hard after school and sometimes has to skip lessons to collect 400 ringgit to take his grandfather to the hospital. The only transportation available is a motorboat passing through the forest. This everyday fact of life that Salman experiences forces him to challenge the common myth about Indonesia as represented in the song Kolam Susu and construct a different meaning as represented in his poem. Salman tries to project a new constructed meaning of Indonesia. In other words, the imagined common myth about Indonesia as represented in the song is challenged with a different projected meaning based on the everyday reality.

The next representation of the national identity in this film is carried out through what the characters do and remember. In this case, there is a contrasting representation as shown in the choices and position that Hasyim and Haris take. As Kolakowski suggests, one element of national identity is the existence of the national spirit or volkgeist which is expressed in collective behaviour especially in the moment of crisis (as cited in Wodak, Celia, Reisigl, \& Liebhart, 2009, p. 25). Hasyim represents this element. Despite his poor health and financial conditions, and also his unfulfilled expectation of the common myth of the prosperity of Indonesia, he still chooses to stay and live in the borderland of Indonesia. Even towards his death, Hasyim is still proud of being an Indonesian and urges Salman to be proud as well.

Hasyim still believes in the common myth of the Indonesian prosperity as represented in the song Kolam Susu. This is expressed when Haris presents a different construction of meaning regarding prosperity. Haris says that Malaysia is more prosperous proven by the real condition of which he himself attests. The portrayal of the physical condition between the border area in Indonesia and that in Malaysia helps to build Haris' construction of meaning. Even the differences of the border road condition between the two countries shown in the film support this construction of meaning. The road on the Malaysian side is wellpaved, whereas on the Indonesian side, it is rocky (Figure 4). Nevertheless, although Haris insists on choosing to stay in Malaysia and becoming a Malaysian citizen by marrying a

Table 1. Comparison between the song Kolam Susu (Pool of Milk) and Salman's Poem.

The Song: Pool of Milk

No seas but pools of milk

Fishing rod and net provide you with means of living adequately, no storms, no typhoons will you meet

Fish and shrimps will come to you

People say our land is heaven land

Sticks and rocks turn to plants

They say our land is heaven land, Sticks and rocks turn to plants

Salman's Poem: Heaven on Earth They Say...

No seas but pools of milk ... they say

But my grandfather says, only rich people can drink milk

Fishing rod and net provide you with means of living adequately, no storms, no typhoons will you meet ... they say

But my grandfather says, the fish are taken by foreign fishermen Fish and shrimps will come to you... they say

But my grandfather says, hush... there is an axe to grind

People say our land is heaven on Earth ... so they say

But dr. Intel says only the officials have it

Sticks and rocks turn to plants ... they say

But dr. Intel says our logs are sold to neighbouring countries

People say our land is heaven on earth,

Sticks and rocks turn to plants ... they say

But my grandfather says, not all people have prosperous life, many officials sell logs and rocks to build their own heaven 


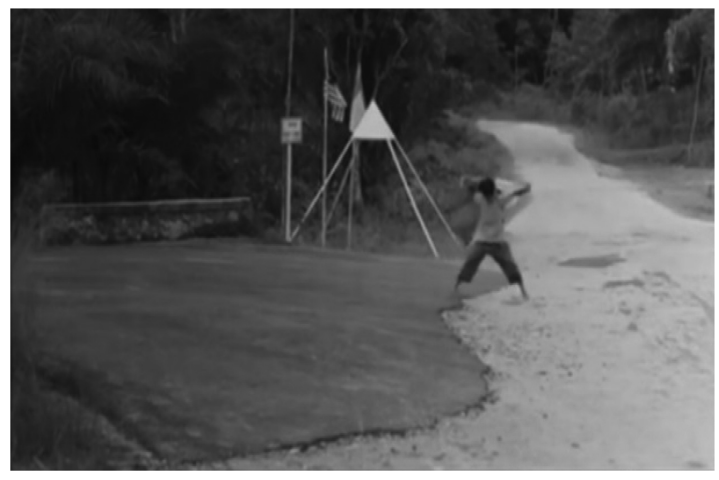

Figure 4. Contrasting infrastructure.

Malaysian woman, he is still emotionally attached to his Indonesian family (i.e. Hasyim and Salman). This can be seen from his expression when he learns about the death of his father. He becomes emotionally disturbed and experiences a moment of loss. Thus, even though Haris positions himself politically and practically as a Malaysian and chooses to stay in Malaysia, he cannot completely sever his cultural identity as an Indonesian. In this sense, he forms multiple identities and undergoes a contestation of identities.

\section{CONCLUSION}

National identity is a social construction of meaning related to the nation which people can identify with. This meaning construction is not fixed once for all, but it is a process that is ongoing in people's life. Furthermore, Edensor (2002) contends that what is called "national" is "constituted and reproduced, contested, and reaffirmed in everyday life" (p. 20). Moreover, Puryanti and Husain's study (2011) highlights the negotiation that the people living in the borderlands can do in relation to "their nation-state in which loyalties are competing and multiple identities are managed on a daily basis" (p. 117). Since people who live in the borderland go in and out of the border, they may form multiple identities. This is what happens to Haris who becomes a Malaysian citizen in order to gain a better living, but who is still culturally attached to his Indonesian family and heritage. Moreover, from the analysis of the film, it can be concluded that the representation of national identity does not only provide a single construction of meaning.

In conclusion, the film Tanah Surga Katanya ... has been successful in representing multiple and competing national identities and raising the awareness of the viewers that although Indonesia has been represented through a myth as a prosperous country in the song Kolam Susu, the reality of life in the borderland presents a contrasting picture. This film raises the awareness that the state needs to pay more attention to the people in the borderland and that national identity is a construction which cannot be encapsulated into a single meaning, but it involves anticipation and future orientations which may contest the present one.

\section{REFERENCES}

Anderson, B. (2006) Imagined Communities: Reflections on the Origin and Spread of Nationalism. London, Verso.

Castells, M. (2010) The Power of Identity. Singapore, Wiley-Blackwell.

Diener, A.C. \& Hagen, J. (2010) Borderlines and Borderlands: Political Oddities at the Edge of the NationState. Lanham, Rowman \& Littlefield Publishers.

Edendor, T. (2002) National Identity, Popular Culture and Everyday Life. Oxford, Berg. 
Hall, S. (1990) Cultural identity and diaspora. In: Rutherford, J. (eds.) Identity: Community, culture, difference. London, Lawrence \& Wishart. pp. 222-237.

Novianto, H. (Director), \& Mizwar, D., Brajamusti, G., \& Nawawi, B. (Producers). (2012) Tanah Surga Katanya ... (Heaven on Earth, They Say...) [DVD]. Indonesia: Demi Gisela Citra Sinema.

Omar, S. (2010) The Indonesian-Malaysian Confrontation. [Online] Available from: http://eresources.nlb. gov.sg/infopedia/articles/SIP_1072_2010-03-25.html.

Puryanti, L., \& Husain, S.B. (2011) A people-state negotiation in a borderland: A case study of the Indonesia-Malaysia frontier in Sebatik island. Wacana: Jurnal Ilmu Pengetahuan Budaya, 13, $105-120$.

Siregar, A.S. (2012) Daftar Pemenang Festival Film Indonesia 2012 (The List of the 2012 Indonesian Film Festival). [Online] Available from: http://www.flickmagazine.net/feature/1511-daftar-pemenang-festival-film-indonesia-2012.html [Accessed December 2012].

Smith, A.D. (1991) National identity. London, Penguin Books.

Wodak, R., Cillia, R. de, Reisigl, M., \& Liebhart, K. (2009) The discursive construction of national identity (A. Hirsch, R. Mitten, \& J. W. Unger, Trans.). Edinburgh, Edinburgh University Press. 